\title{
RELATIONSHIPS BETWEEN ENVIRONMENTAL FACTORS AND VegetATION IN NUTRIENT-ENRICHED FENS AT FISHPOND MARGINS
}

\author{
Jana Navrátilová ${ }^{1)}$, Josef Navrátil ${ }^{2)}$ \& Michal Hájek ${ }^{3)}$ \\ 1) Masaryk University, Faculty of Science, Department of Botany, Kotlářská 2, CZ-611 37 Brno, Czech \\ Republic, and Department of Plant Ecology, Institute of Botany, Academy of Sciences, Dukelská 135, CZ-379 82 \\ Treboň, Czech Republic, e-mail janaernestova@seznam.cz \\ 2) University of South Bohemia, Faculty of Agriculture, Vančurova 2904, CZ-390 01 Tábor, Czech Republic, \\ e-mailjnav@centrum.cz \\ 3) Masaryk University, Faculty of Science, Department of Botany, Kotlářská 2, CZ-611 37 Brno, Czech \\ Republic, and Department of Ecology, Institute of Botany, Academy of Sciences, Pořičí 3b, CZ-603 00 Brno, \\ Czech Republic; e-mail hajek@sci.muni.cz
}

\begin{abstract}
Vegetation-environment relationships were investigated in fens of the Třeboň basin (Czech Republic), which are enriched by nutrients and calcium from intensively managed and limed fishponds to test the hypothesis of altered gradient structure after long-term nutrient enrichment in fens. Water-table depth, $\mathrm{pH}$, conductivity, $\mathrm{N}-\mathrm{NH}_{4}^{+}, \mathrm{N}-\mathrm{NO}_{3}^{-}, \mathrm{PO}_{4}^{3-}$, total $\mathrm{P}, \mathrm{SO}_{4}^{2-}, \mathrm{K}^{+}, \mathrm{Ca}^{2+}, \mathrm{Mg}^{2+}$ and $\mathrm{Fe}$ were measured four times in 30 vegetation plots of $16 \mathrm{~m}^{2}$ during the 2004 vegetation season. Both constrained and unconstrained ordination (DCA, CCA) were used to relate environmental factors to the species composition of the vegetation. The relationships among particular factors were revealed using PCA. Four fen vegetation types obtained by TWINSPAN classification were compared with measured factors using repeated measures ANOVA. Vegetation types differed significantly in water-table depth, water $\mathrm{pH}$ and $\mathrm{Ca}^{2+}, \mathrm{Mg}^{2+}, \mathrm{K}^{+}$, and $\mathrm{N}_{-} \mathrm{NO}_{3}^{-}$content. The concentration of major nutrients fluctuated noticeably during vegetation season and displayed large variation within vegetation types. Temporarily the concentration of different nutrients reached extremely high values. However, high nutrient supply has not altered the gradient structure of the vegetation. Water $\mathrm{pH}$ and water-table depths were found to be two major determinants of species variation in fishpond-margin fens, as in the majority of other environments studied throughout the Northern Hemisphere. Species richness of both vascular plants and bryophytes was partly explained by $\mathrm{pH}$. However, the extent of variation in total mineral richness and potassium concentration were the next two most important variables determining bryophyte species richness. Water in flooded poor-fen vegetation, directly affected by water from limed fishponds, had calcium and magnesium concentration similar to fishpond water. The calcium concentrations of about $20 \mathrm{mg} \mathrm{l}^{-1}$ in typical poor-fen vegetation have no analogy in the ecological literature. High phosphorus level presumably buffers the effect of calcium by enhancing bryophyte biomass depositing superfluous calcium. In conclusion, extremely high long-term nutrient supply to fishpond-margin fens have not altered gradient structure, but shifted chemical limits of plant communities.
\end{abstract}

Keywords: Central Europe, Fluctuation, Třeboň, Vegetation, Water level and chemistry, Wetlands

Nomenclature: KUBÁT et al. (2002), KUČERA \& VÁŇA (2003)

\section{INTRODUCTION}

A long tradition of exploring vegetation-environmental relationships in mires started decades ago in Scandinavia (e.g. DU RIETZ 1949, SJÖRS 1952). The research continues in several parts of the world. Many studies agree that base richness and water regime are the 
major determinants controlling floristic variation in mires (e.g. TAHVANAINEN et al. 2002, JOHNSON \& STEINGRAEBER 2003, HÁJKOVÁ \& HÁJEK 2004, NEKOLA 2004). The disaccord occurs when the role of nutrient availability is considered. WHEELER \& PROCTOR (2000) in their review paper, stressed the fertility gradient, which is connected to nutrient availability, while ØKLAND et al. (2001) did not find any support for this gradient within Fennoscandian mires. The majority of Fennoscandian studies, indeed, refer to the pristine regions in the boreal zone and in the mountains. The Central- and western-European mires, however, have often survived as islands in agricultural and strongly eutrophicated landscape (KOERSELMAN et al. 1990, PAULISSEN et al. 2004) and serve as refugia for many threatened plants and animals. Some recent studies in mire ecology suggest that increasing input of available nutrients could alter the chemical limits of plant communities. Poor Sphagnum-fens could be developed under more calcareous conditions, for example (KOOIJMAN \& KANNE 1993, GUNNARSSON et al. 2000, HÁJEK et al. 2002, HÁJKOVÁ \& HÁJEK 2003, PAULISSEN et al. 2004). Another consequence of enhanced nutrient supply is the proportion of ubiquitous species increasing to the detriment of mire specialist (FOJT \& HARDING 1995, PAULI et al. 2002). In this study, we will test the hypothesis of altered gradient structure after long-term nutrient enrichment. As there are some indices that high nutrient supply can induce a change from rich-fen to poor-fen vegetation, we will test whether even long-term and intense nutrient supply is strong enough to suppress base richness as the major environmental determinant of variation in species composition of fens.

Base richness seems to be the major control of vegetation variation and species richness in mires (e.g. CHYTRÝ et al. 2003, SCHUSTER \& DiEKMAN 2003, HÁJKOVÁ \& HÁJEK 2003, TAHVANAINEN 2004). However, the next important factor for variation in species richness at the local scale is its relationship with productivity and the species richness-productivity patterns are influenced by the kind of nutrient limitation (OLDE VENTERINK et al. 2003). OLDE VENTERINK et al. (2001) have found that in fens a similar share of variation in species density was explained by biomass the same way as by environmental factors not related to biomass; they also have found density of threatened species increasing with decreasing P availability even within low-productive fens. CHAPIN et al. (2004) showed that nutrient effects on above-ground net primary production differ between base-rich and acidic mires as well as among principal functional groups. Moreover, several studies reported the change of species-rich fens towards species-poor Sphagnum-dominated fens probably caused by raised nutrient supply under unchanged calcium concentration (HEDENÄS \& KOOIJMAN 1996a, GUNNARSSON et al. 2000, BELTMAN et al. 2001, HÁJEK et al. 2002). There is therefore a presumption that such a variable influence of nutrient enrichment to species-richness and productivity patterns could eliminate the role of $\mathrm{pH}$ in determining plant species richness under extremely high nutrient input.

The next major objective of this study will be testing the presumably synergistic effect of base saturation, nutrient enrichment and fluctuation in environmental variables to the floristic diversity of fen vegetation in an agricultural landscape. In spite of high nutrient and calcium supply to extensively managed fishponds, there are some remnants of regionally exceptional vegetation full of rare, threatened and relic plants in adjacent fens (NAVRÁTILOVÁ \& NAVRÁTIL 2005a) suggesting that these fens are somehow buffered against negative 
influence of eutrophicated pond water. The large fluctuation of environmental factors found in fishpond-margin mires (NAVRÁTILOVÁ \& NAVRÁTIL 2005b) could be a key to understanding this phenomenon. Many studies in mire ecology have shown that the extent of the variation in environmental factors would become a separate factor in itself, more important than mean or median value (DIERSCHKE 1969, RYBNÍČEK 1974, WIERDA et al. 1997, ASADA 2002, HÁJKOVÁ et al. 2004). For example, the fluctuation of water level causes that vegetation, bottom layer especially, is under direct influence of eutrophicated water only during a part of the year. The important issue we have to know if we want to assess the effect of high nutrient supply to fen vegetation is whether fluctuation of water chemistry variables is synchronized with water level fluctuation. We therefore hypothesize that multidimensional analysis of all environmental factors will explain recent vegetation patterns better than single factors.

The mires at fishpond margins in the Třeboň basin (southern Bohemia, Czech Republic) whose chemical conditions are closely connected to the intensively managed and fertilized fishpond ecosystem (LAZAR 1978, PECHAR et al. 2002) represent a unique model habitat to test the hypotheses about altered gradient structure of fen vegetation subjected to long-term nutrient enrichment.

\section{MATERIALS AND METHODS}

\section{Study sites}

Minerotrophic mires around the fishponds of the Třeboň Basin region, in the southern part of the Czech Republic, offer a good opportunity to study the above-mentioned relationships. The 15 most representative and accessible fens were chosen for this study (Fig. 1). The climate is temperate with a mean annual temperature of $7.8^{\circ} \mathrm{C}$, the mean annual temperature of the coldest month (January) of $-2.2{ }^{\circ} \mathrm{C}$, the mean annual temperature of the warmest month (July) of $17.7^{\circ} \mathrm{C}$ and average annual precipitation of $627 \mathrm{~mm}$ (VESECKÝ 1961). Geological substrate of the Třeboň basin is quite uniform. Siliceous cretaceous and tertiary sandstones and sandy deposits overlying granite bedrock dominate the bedrock. Some of the aquifers are rich in $\mathrm{Fe}$ and/or alkaline ions. Arterial water springs and/or inflow from surrounding areas and/or pond water as well as precipitation saturate the mires. In most cases, the water has low electrolyte concentration relative to non-siliceous bedrock except for sites influenced mainly by pond water and spring areas. However, properties of water sources are not well known because of the mixed influence of these four sources on all sites. The mires have been affected by human activities such as peat mining, fish farming and agriculture. Poor fens are the most common ones among mire vegetation types, rich fens are rarer and are often located in spring areas.

\section{Vegetation data}

Plots were selected subjectively after a thorough investigation of all fen vegetation types (during 2002-2003) to maximize variation in vegetation and environmental conditions in the Třeboň basin. Thirty plots on 15 localities (Fig. 1) were selected; numbers of plots in one locality vary by largeness and diversity of the locality. In most cases there is one plot of one 


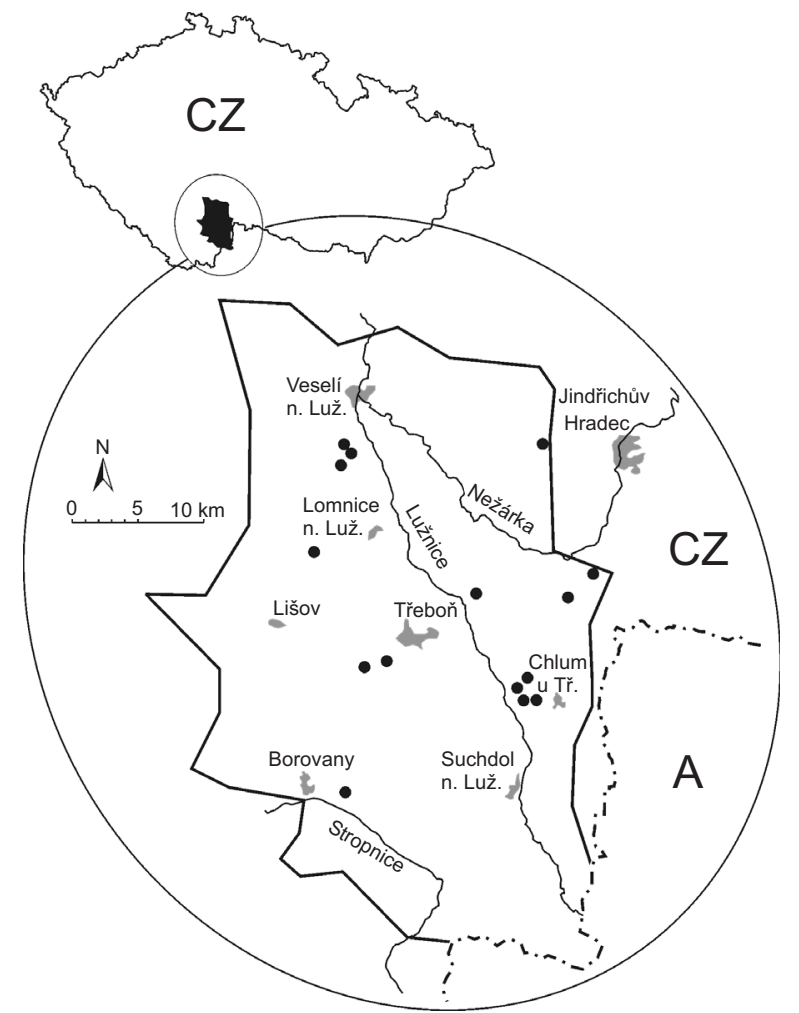

Fig. 1. Location of the study sites.

vegetation type from one locality, except for large and diverse localities. Selected plots thus represent all main mire vegetation types in the study area (for method see also SOMODI \& BOTTA-DUKÁT 2004). Species composition was recorded in 2004, during the summer when the vegetation is in optimum. The plot size was always $4 \times 4 \mathrm{~m}$. The cover of both vascular plants and bryophytes was recorded using the nine-grade scale (VAN DER MAAREL 1979). The height of the vegetation cover was measured to indirectly approximate the productivity of the vegetation.

\section{Environmental factors}

The water-table depth was measured manually in PVC tubes perforated throughout their length. PVC tubes were placed in the central part of each of the 30 sampling plots. The water was always pumped out of the PVC tubes and allowed to refill before sampling. Water $\mathrm{pH}$ and conductivity, both standardized at $20^{\circ} \mathrm{C}$, were measured in situ using portable instruments (PH 114, CM 113, Snail Instruments, Czech Republic). Conductivity caused by $\mathrm{H}^{+}$ions in acid waters was subtracted (SJÖRS 1952). Water samples were collected from the same permanent plots (PVC tubes). Water was placed in plastic bottles and transported to the laboratory within two to twelve hours. The contact of sampled water with air was short in all cases. Prior to further analyses, water samples were filtered through a $1.2 \mu \mathrm{m}$ filter. 
Water samples were collected also from the pond neighbouring each site. The pond sampling sites were selected in open water nearest to each fen and were marked with a bamboo stake. The variation of water level in the pond was measured with respect to these stakes. Pond water samples were collected near the water surface.

Anions were analyzed after chemical reaction spectrofotometrically with FIA (Tecator, Sweden) flow analyzer. The principle of determination of $\mathrm{N}_{-} \mathrm{NH}_{4}^{+}$(ammonia nitrogen) is that the aqueous sample containing ammonium ions is injected into a carrier stream, which is merged with a sodium hydroxide stream. In the resulting alkaline stream gaseous ammonium is formed that may diffuse through a gas permeable membrane into an indicator stream. This indicator stream comprises a mixture of acid-base indicators, HI, where I denotes the indicator anions. The ammonia gas reacts with $\mathrm{HI}$ and the anion concentration of the indicators will increase. The resulting colour shift can be measured photometrically. $\mathrm{N}_{-} \mathrm{NO}_{3}^{-}$(nitrate) was firstly reduced to nitrite passing the sample through a copperized cadmium reductor. The nitrite reacts with sulphanilamide in an acidic solution to form a diazo compound. The diazotized product is the coupled with N-(I-naphtyl)-ethylenediamine dihydrochloride. The intensity of the formed azo dye, which is proportional to the sum of the nitrate and nitrite originally present in the sample, is the measured at $540 \mathrm{~nm}$; orthophosphate $\left(\mathrm{PO}_{4}^{3-}\right)$ was determined after reaction with ammonium molybdate to form the heteropoly molybdophosphoric acid, which is reduced in a second step to phosphomolybdenum blue by stannous chloride in a sulphuric acid medium. The intensive blue colour of the formed heteropoly compound is measured at $690 \mathrm{~nm}$; total phosphorus was determined identically as orthophosphates after the mineralization by $\mathrm{HClO}_{4}$, and hydrolysis of not dissolved pyrophosphates in a high temperature; $\mathrm{SO}_{4}^{2-}$ were determined by method of methyl-thymol blue in alkaline solution. Cations were determined by atomic sorbefacient spectrophotometry with SectrAA 640 (Varian Techtron, Australia) by flame method. $\mathrm{K}^{+}, \mathrm{Mg}^{2+}$ and total $\mathrm{Fe}$ in the flame of acetylene-air, $\mathrm{Ca}^{2+}$ in the flame of $\mathrm{N}_{2} \mathrm{O}$-acetylene. Detecting limits for anion determination were $10 \mu \mathrm{gl}^{-1}\left(20 \mu \mathrm{gl}^{-1}\right.$ for total $\left.\mathrm{P}\right)$, and for cations were $0.01 \mathrm{ppm}$ for $\mathrm{K}^{+}, \mathrm{Mg}^{2+}$ and total $\mathrm{Fe}$, and $0.02 \mathrm{ppm}$ for $\mathrm{Ca}^{2+}$. The laboratory used has interlaboratory calibration tests ASLAB.

Because previous studies showed noticeable fluctuation of major nutrient concentrations in fens (VITT at al. 1995, TAHVANAINEN et al. 2003, HÁJEK \& HEKERA 2004), water chemistry was sampled four times a year from April to September 2004 in all plots. This period corresponds to the growing season in Central Europe when the water regime has the greatest influence on peat vegetation. The first set of measurements was conducted at the beginning of the growing season (11th April), second and third during the growing season (1st June, 5th August) and fourth at the end of growing season (28th September).

\section{Statistical analysis}

Three related multivariate statistical techniques were used to analyze vegetation data: two-way indicator species analysis (TWINSPAN), detrended correspondence analysis (DCA), and canonical correspondence analysis (CCA). Each approach provides a somewhat different view of data structure and when employed together the techniques can be used to complement, supplement, and evaluate the other analyses (ØKLAND 1996, LEPŠ \& ŠMILAUER 
Table 1. Four vegetation types classified by the second division of TWINSPAN. Species with considerable fidelity (phi coefficient above 25) were selected as a diagnostic species.

\begin{tabular}{|c|c|c|c|c|c|c|}
\hline No. & Name & Dominant species & Diagnostic species & $\begin{array}{l}\text { Average } \\
\text { lumber of } \\
\text { pecies per } \\
\text { plots }\end{array}$ & s.e. & $\begin{array}{l}\text { No. of } \\
\text { plots }\end{array}$ \\
\hline 1 & Flooded fen & $\begin{array}{l}\text { Sphagnum denticulatum, } \\
\text { S. palustre }\end{array}$ & $\begin{array}{l}\text { Utricularia intermedia, Carex } \\
\text { elata, Juncus bulbosus, Lycopus } \\
\text { europaeus, Sphagnum denticulatum }\end{array}$ & 10 & 2 & 5 \\
\hline 2 & Poor fen & $\begin{array}{l}\text { Sphagnum fallax, } \\
\text { S. papillosum }\end{array}$ & $\begin{array}{l}\text { Utricularia ochroleuca, } \\
\text { Polytrichum commune, Sphagnum } \\
\text { fallax, S. papillosum }\end{array}$ & 10 & 2 & 10 \\
\hline 3 & $\begin{array}{l}\text { Medium-rich } \\
\text { fen }\end{array}$ & $\begin{array}{l}\text { Calliergonella cuspidata, } \\
\text { Sphagnum flexuosum, } \\
\text { S. teres }\end{array}$ & $\begin{array}{l}\text { Agrostis canina, Carex chordorrhiza, } \\
\text { C. nigra, Equisetum fluviatile, } \\
\text { Lysimachia thyrsiflora, Menyanthes } \\
\text { trifoliata, Drepanocladus exannulatus, } \\
\text { D. vernicosus, Sphagnum platyphyllum, } \\
\text { S. teres, etc. }\end{array}$ & 21 & 2 & 12 \\
\hline 4 & Rich fen & Sphagnum palustre & $\begin{array}{l}\text { Carex davalliana, C. dioica, } \\
\text { Parnassia palustris, Potentilla erecta, } \\
\text { Rhynchospora alba, Trichophorum } \\
\text { alpinum, Utricularia minor, Aneura } \\
\text { pinguis, Drepanocladus cossonii, } \\
\text { Homalothecium nitens, Sphagnum } \\
\text { contortum, S. subnitens, S. warnstorfii, et }\end{array}$ & $\begin{array}{l}38 \\
\text { etc. }\end{array}$ & 3 & 3 \\
\hline
\end{tabular}

2003). Vegetation data were classified using TWINSPAN - a polythetic divisive classification method that uses two-way indicator species analysis (HILL 1979). Pseudospecies cut levels were set at 0,5 and $25 \%$ to suit the dataset composed of percent frequency. We used classification at the level of four groups (Table 1). Differences of species number of the vegetation types were evaluated by Kruskal-Wallis test. The concentration of species occurrences in vegetation type (fidelity) was calculated by phi coefficient (CHYTRÝ et al. 2002) to show the species that characterize particular vegetation types.

Gradients in species composition of the vegetation in relation to the environment were assessed using detrended correspondence analysis (DCA) and canonical correspondence analysis (CCA) algorithms of the CANOCO 4.5 package (TER BRAAK \& ŠMILAUER 2002). The percentage frequency of the species was log-transformed and rare species were downweighted.

The vegetation data set was subjected first to DCA in order to assess the overall variation patterns in species composition independent from environmental factors measured. Ordination site scores were correlated to means, medians, minimum, maximum and coefficient of variation of all measured environmental factors using Kendall tau. Medians and coefficients of variation of all environmental variables were plotted onto DCA ordination diagrams as supplementary environmental data for better ecological interpretation of the axes. 
The same analysis was performed separately for bryophyte subset and for vascular plant subset.

Subsequently we used CCA to test the ability of each measured factor to explain variation in species composition of the vegetation and to find the measured factors explaining maximum variation in species data under minimum number of variables involved into constrain ordination model (so-called forward selection procedure, see TER BRAAK \& ŠMILAUER 2002, LEPŠ \& ŠMILAUER 2003). The parameters obtained from consecutive measurements may have different significance in explaining vegetation gradients. Therefore, five statistical parameters (mean, median, minimum, maximum, and coefficient of variation) obtained from consecutive measurement of each environmental factor were used in the analyses. The effect of the first canonical axis was tested by permutation test (499 permutations were always used). To test the statistical significance of the second canonical axis we calculated partial CCA where the first axis was partialled out by using it as a covariable. Significance was again tested by the permutation test. The factors were stepwise added into the model with a threshold of $P<0.05$ to entry.

Principal components analysis (PCA) was used for indirect ordination of environmental data with an objective to find main gradients in the water chemistry of all studied sites and to test whether sites similar in environmental conditions as a whole harbour the same vegetation type. In addition to environmental variables from 30 fens, environmental data from 10 fishponds were subjected to analysis to find out how the chemistry of pond water is similar to the chemistry of each vegetation types. Four values obtained from repeated measurement of each environmental variable were used. The values of measured environmental variables were log-transformed to approximate normal distributions. However, the water-level data from fishponds were excluded. The values of each environmental variable were standardized to mean 0 and variance 1 in PCA analysis. Medians and coefficients of variation of environmental variables related to 1st and 2nd axes were plotted onto PCA ordination diagrams as supplementary environmental data, instead of species display, for better clarity of the diagram. Correlations between water chemistry of four fen types and fishpond water were tested by Pearson correlation coefficient.

The seasonal trends in fluctuation of environmental factors and the differences in measured factors among communities and fishpond water, respectively, were investigated using repeated measures analysis of variance (RMANOVA). The relationships between species richness (dependent variable) and means, medians, minima, maxima and coefficients of variation of measured environmental factors, cover of each individual vegetation layer and height of herb layer were evaluated by stepwise multiple linear regression using forward variable selection with a threshold of $P<0.05$ to entry. The relationships between each of these environmental variables and species richness were correlated using Kendall tau correlation coefficient.

\section{RESULTS}

\section{Gradient analysis}

The first two DCA axes were nearly equal in length (Fig. 2) and together explained about $21 \%$ of the total species variability (Table 2 ). They also correlated very well with 


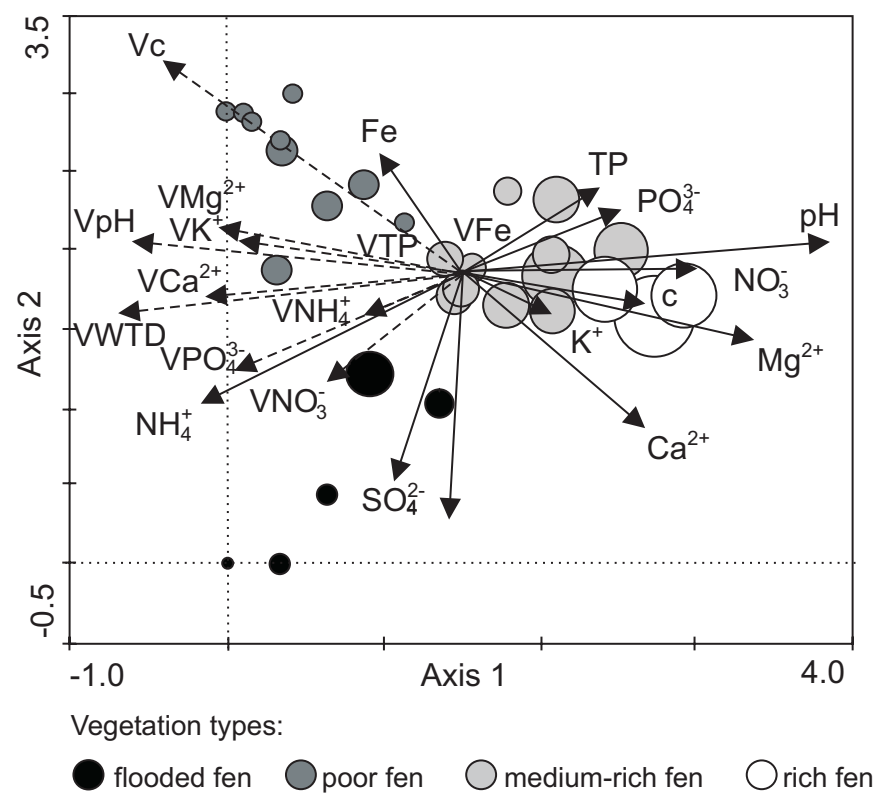

Fig. 2. DCA simple ordination plot of samples with the environmental variables passively projected onto the ordination. The size of the symbols corresponds to species richness (number of species in relevé). Species scores along the first and second DCA axes are in Appendix. (WTD - water-table depth, TP - total phosphorus, c conductivity, "V" before symbol of variable is coefficient of variation).

environmental data; species-environment correlations (see TER BRAAK \& ŠMILAUER 1998, LEPŠ \& ŠMILAUER 2003) along first two axes are high $\left(r_{1 \text { st ax. }}=0.963 ; r_{2 \text { nd ax. }}=0.846\right)$.

The first ordination axis was correlated significantly with $\mathrm{pH}$ (mean, median, minimum and variation), $\mathrm{Ca}^{2+}$ (minimum and variation), variation of $\mathrm{Mg}^{2+}$, variation of conductivity, variation of water-table depth and $\mathrm{NH}_{4}^{+}$(median). The second ordination axis was significantly correlated with water level (median), conductivity (minimum and variation), $\mathrm{Ca}^{2+}$ (mean, median and minimum), $\mathrm{Mg}^{2+}$ (min), and Fe (mean and median) (Table 3). We can generalize that not only $\mathrm{pH}$ but also all measured variation in environmental variables were negatively correlated with the first DCA axis. Along the first axis rich fens were clearly separated from poor fens (poor-rich gradient). Along the second axis the poor fens were divided into flooded ones and non-flooded ones. The general pattern remained the same in the DCA of bryophyte subset. In DCA of the vascular plant subset, the gradient of base richness was not so clear. The poor fens were in the middle of the gradient and were surrounded by the other vegetation types. This pattern can be partly explained by the broader ecological amplitude of the majority of vascular plants relative to bryophytes.

CCA was applied to test the hypothesis about the influence of base richness and water level on the species composition of the vegetation. The variables that most effectively and significantly explained the species composition of the plant communities were minimum $\mathrm{pH}$, maximum water table, maximum $\mathrm{K}^{+}$and minimum $\mathrm{PO}_{4}^{3-}$ (Fig. 3). Together they explained about $25 \%$ of the total variability. The first two canonical axes captured most of the variation of the species data (about 18\%). The results of the permutation test showed that both the first 
Table 2. Summary of detrended correspondence analysis (DCA), partial detrended correspondence analysis of vascular plants (DCAv), of mosses (DCAm), canonical correspondence analysis (CCA) of 30 fen types, and principal component analysis (PCA) of 30 fen types and 10 ponds.

\begin{tabular}{lcccccc} 
& Axis & DCA & DCAv & DCAm & CCA & PCA \\
\hline Eigenvalue & 1 & 0.464 & 0.448 & 0.815 & 0.356 & 0.319 \\
& 2 & 0.326 & 0.282 & 0.537 & 0.303 & 0.162 \\
& 3 & 0.191 & 0.162 & 0.380 & 0.147 & 0.089 \\
& 4 & 0.013 & 0.098 & 0.185 & 0.106 & 0.065 \\
Tength of gradient & Total inertia & 3.712 & 3.101 & 5.399 & 3.712 & \\
& 1 & 2.919 & 2.798 & 5.879 & & \\
Species environment correlation & 2 & 2.990 & 2.750 & 4.767 & & \\
& 3 & 2.587 & 2.425 & 4.735 & & \\
& 4 & 1.800 & 1.521 & 2.898 & & \\
Cumulative percentage variance & 1 & 0.963 & 0.825 & 0.965 & 0.911 & 0.985 \\
Species data & 2 & 0.846 & 0.923 & 0.943 & 0.881 & 0.979 \\
& 3 & 0.834 & 0.976 & 0.979 & 0.874 & 0.977 \\
& 4 & 0.982 & 0.951 & 0.800 & 0.823 & 0.939 \\
Species-environmental relations & 1 & 12.5 & 14.5 & 15.1 & 9.6 & 31.9 \\
& 2 & 21.3 & 23.6 & 25.0 & 17.8 & 48.1 \\
& 3 & 26.4 & 28.8 & 32.1 & 21.7 & 57.0 \\
& 4 & 29.9 & 31.9 & 35.5 & 24.6 & 63.5 \\
& 1 & 13.9 & 11.3 & 15.8 & 39.0 & 35.6 \\
& 2 & 21.2 & 21.4 & 26.3 & 72.2 & 53.4 \\
& 3 & 0.0 & 0.0 & 0.0 & 88.3 & 63.2 \\
& 4 & 0.0 & 0.0 & 0.0 & 100.0 & 69.8 \\
\hline
\end{tabular}

and second axes are significant $(P<0.01)$, demonstrating that the relationship between the species occurrences and the environmental variables was highly significant. Eigenvalues of the first two axes in CCA are only slightly smaller than those in DCA, and species-environmental correlations in CCA for the first two axes are high $\left(r_{1 \text { st ax. }}=0.911\right.$, $\left.r_{2 \text { nd ax. }}=0.881\right)$. This indicates that the variables included in CCA really captured much of the variation in the species data. These findings were supported by similar ordination patterns in DCA and CCA. Rich fens and moderately rich fens were divided from poor fen according to $\mathrm{pH}$ values. Flooded fens were not clearly separated in CCA from non-flooded poor fens, indicating that maximum water level cannot solely explain the clear floristic differences among them.

The first two axes in PCA of water-chemistry factors explain the most of the variability in the environmental data (48\%). The first axis represented the $\mathrm{pH}$ and conductivity of water and concentrations of major cations $\left(\mathrm{Ca}^{2+}, \mathrm{Mg}^{2+}, \mathrm{K}^{+}\right), \mathrm{SO}_{4}^{2-}$, and $\mathrm{NO}_{3}^{-}$, the second axis the concentrations of $\mathrm{NH}_{4}^{+}, \mathrm{PO}_{4}^{3-}$, total P (Fig. 4). The pond sites were separated from other fen sites. However, the constituent fen types were not clearly separated. The poor-rich gradient was only slightly outlined. The rich-fen samples were close to fishpond ones in the diagram although they occurred on springs that are not influenced by pond water. This is evidently caused by high values of $\mathrm{pH}, \mathrm{Ca}^{2+}, \mathrm{K}^{+}$and conductivity (Table 4). 
Table 3. Kendall tau correlation coefficients between environmental variables and ordination axes of DCA (see Fig. 2). Significance levels: ${ }^{*}-P<0.05, * *-P<0.01, * * *-P<0.001$, n.s. - not significant.

\begin{tabular}{|c|c|c|c|c|c|c|}
\hline \multirow[t]{2}{*}{ Environmental variable } & \multicolumn{2}{|c|}{ DCA (Total data set) } & \multicolumn{2}{|c|}{ DCA (Vascular plants) } & \multicolumn{2}{|c|}{ DCA (Mosses) } \\
\hline & Axis 1 & Axis 2 & Axis 1 & Axis 2 & Axis 1 & Axis 2 \\
\hline Mean water table depth & n.s. & n.s. & n.s. & n.s. & n.s. & $-0.34 * *$ \\
\hline Median water table depth & n.s. & $-0.26^{*}$ & n.s. & n.s. & n.s. & $-0.38 * *$ \\
\hline Maximum water table depth & n.s. & n.s. & $-0.35 * *$ & n.s. & n.s. & $-0.28 *$ \\
\hline Variation of water table depth & $-0.34 * *$ & n.s. & n.s. & n.s. & $0.27^{*}$ & n.s. \\
\hline Mean $\mathrm{pH}$ & $0.47 * * *$ & n.s. & n.s. & n.s. & $-0.43 * * *$ & n.s. \\
\hline Median $\mathrm{pH}$ & $0.44 * * *$ & n.s. & n.s. & n.s. & $-0.36 * *$ & n.s. \\
\hline Minimum $\mathrm{pH}$ & $0.44 * * *$ & n.s. & n.s. & n.s. & $-0.44 * * *$ & n.s. \\
\hline Variation of $\mathrm{pH}$ & $-0.38 * *$ & n.s. & n.s. & n.s. & $0.47 * * *$ & n.s. \\
\hline Median conductivity & n.s. & n.s. & n.s. & n.s. & n.s. & $-0.28 *$ \\
\hline Minimum conductivity & n.s. & $-0.27 *$ & n.s. & n.s. & $-0.31 *$ & $-0.36^{* *}$ \\
\hline Variation of conductivity & $-0.31 * *$ & $0.36^{*}$ & n.s. & n.s. & $0.41 * *$ & $0.37 * *$ \\
\hline Mean $\mathrm{Ca}^{2+}$ & n.s. & $-0.28 *$ & n.s. & n.s. & n.s. & $-0.27 *$ \\
\hline Median $\mathrm{Ca}^{2+}$ & n.s. & $-0.27 *$ & n.s. & n.s. & $-0.26^{*}$ & $-0.29 *$ \\
\hline Minimum $\mathrm{Ca}^{2+}$ & $0.38 * *$ & $-0.29 *$ & n.s. & n.s. & $-0.38 * *$ & $-0.27 *$ \\
\hline Variation of $\mathrm{Ca}^{2+}$ & $-0.27 *$ & n.s. & n.s. & n.s. & $0.27 *$ & n.s. \\
\hline Median $\mathrm{Mg}^{2+}$ & n.s. & n.s. & n.s. & n.s. & $-0.26^{*}$ & $-0.29 *$ \\
\hline Minimum $\mathrm{Mg}^{2+}$ & n.s. & $-0.26^{*}$ & n.s. & n.s. & $-0.31 *$ & $-0.31 *$ \\
\hline Variation of $\mathrm{Mg}^{2+}$ & $-0.28 *$ & n.s. & n.s. & n.s. & $0.30 *$ & n.s. \\
\hline Mean Fe & n.s. & $0.31 *$ & n.s. & n.s. & n.s. & n.s. \\
\hline Median Fe & n.s. & $0.33^{*}$ & n.s. & n.s. & n.s. & n.s. \\
\hline Mean $\mathrm{NH}_{4}^{+}$ & n.s. & n.s. & n.s. & $-0.27^{*}$ & n.s. & n.s. \\
\hline Median $\mathrm{NH}_{4}^{+}$ & $-0.26^{*}$ & n.s. & n.s. & $-0.33^{*}$ & n.s. & n.s. \\
\hline Maximum $\mathrm{NH}_{4}^{+}$ & n.s. & n.s. & $-0.26^{*}$ & $-0.27 *$ & n.s. & n.s. \\
\hline Minimum $\mathrm{NO}_{3}^{-}$ & n.s. & n.s. & $0.36 * *$ & n.s. & n.s. & n.s. \\
\hline Minimum of total $\mathrm{P}$ & n.s. & n.s. & $-0.27^{*}$ & n.s. & n.s. & n.s. \\
\hline Maximum of total $\mathrm{P}$ & n.s. & n.s. & $-0.31^{*}$ & n.s. & n.s. & n.s. \\
\hline $\mathrm{SO}_{4}^{2-}$ content & n.s. & n.s. & n.s. & n.s. & n.s. & $-0.27^{*}$ \\
\hline
\end{tabular}

\section{Temporal fluctuation of environmental factors}

There are marked seasonal trends in fluctuations of the measured parameters. Fluctuation was more considerable in flooded- and poor fens than in rich- and moderately rich fens (Fig. 5). For example, water level amplitude was about $20 \mathrm{~cm}$ in poor fens, but only about $5 \mathrm{~cm}$ in rich fens. In 2003, the same pattern was found in fluctuation of $\mathrm{pH}$ and conductivity (NAVRÁTILOVÁ \& NAVRÁTIL 2005b). General trends could be detected in fluctuation of water level, $\mathrm{pH}$, conductivity, $\mathrm{Ca}^{2+}, \mathrm{Mg}^{2+}$. Water table depth decreased in summer when evapotranspiration was higher and rose in autumn after rainfalls. The $\mathrm{pH}$ increased from spring to summer and decreased at the end of vegetation season. The lowest conductivity occurred in the spring, increased continuously throughout summer; and reached highest values in autumn. The trends in fluctuation of main cations are similar to the trend in conductivity. The anion concentrations fluctuate noticeably during vegetation season. In contrast to other measured factors, the anions (except $\mathrm{NO}_{3}^{-}$) showed no significant difference among the four defined vegetation types. In addition, there were considerable differences even within vegetation types. Further, the fluctuation of anions within vegetation types is, in some cases, bigger than the differences among vegetation types. 


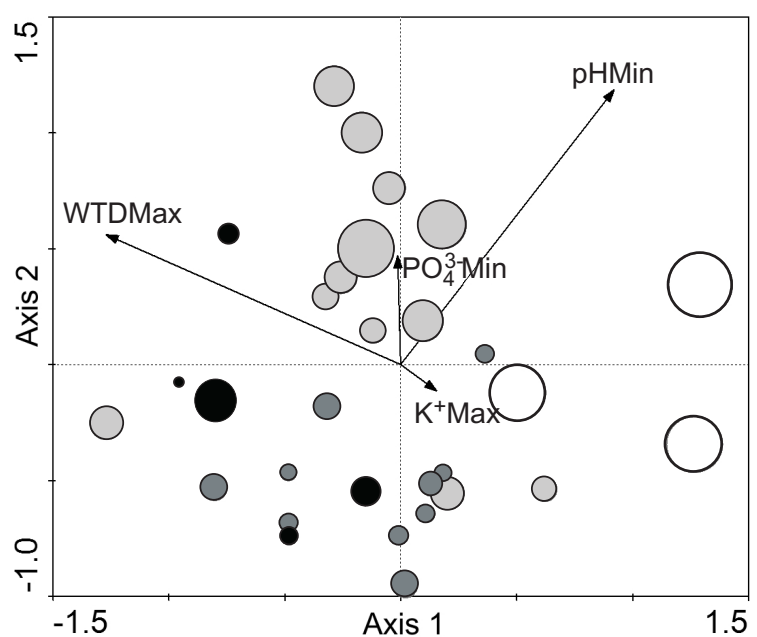

Fig. 3. Position of vegetation types according to four water parameters selected by forward selection algorithm in CCA (for legend see Fig. 2).

\section{Comparison of environmental factors across vegetation types}

The means and standard errors of environmental parameters in the four vegetation types are shown in Table 4. Between-subject (TWINSPAN clusters) effect of RMANOVA was significant for water-table depth, water $\mathrm{pH}, \mathrm{Ca}^{2+}, \mathrm{Mg}^{2+}, \mathrm{K}^{+}$and $\mathrm{NO}_{3}^{-}$. Within-subject effect (seasonal fluctuation) of RMANOVA was significant for water-table depth, water $\mathrm{pH}$, conductivity, $\mathrm{Ca}^{2+}, \mathrm{Mg}^{2+}, \mathrm{Fe}$, and $\mathrm{NO}_{3}^{-}$. In some cases, the anion concentrations reached extremely high levels that have not been found in unpolluted fens (see Table 5 and Discussion).

\section{Relationships between species richness and environmental factors}

In a multiple linear regression, species richness of vascular plants correlated positively with minimum $\mathrm{pH}$ and negatively with both maximum water table and total percentage cover of the vegetation (Table 6). Total species richness mirrored this trend as it was governed by the richer taxonomical group, vascular plants. Fluctuation of $\mathrm{K}^{+}$, however, accounted for a substantial part in species richness variation of bryophytes, followed by ammonium concentration, water-table depth and total vegetation cover. To test whether the effect of fluctuation of $\mathrm{K}^{+}$and ammonium concentration could be only correlative of base saturation (fluctuation of $\mathrm{K}^{+}$and ammonium increased towards poor fens), we eliminated these variables from the model and repeated the multiple regression. The variance of bryophyte species richness explained by the included factors did not change markedly, but the factors involved in the model have changed. The extent of seasonal variation in conductivity, i.e., variation in mineral richness, became the major predictor. When it was further eliminated, the explained variance was reduced by $25 \%$. Further, when both variations in conductivity and maximum $\mathrm{K}^{+}$concentration were eliminated, the explained variance was reduced even by $50 \%$. Hence, bryophyte species richness is controlled mostly by the extent of fluctuation of environmental 


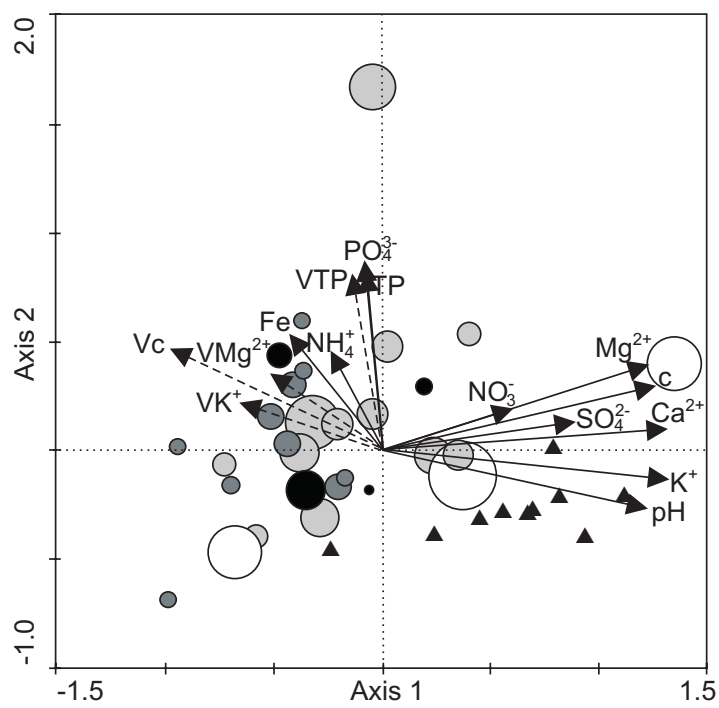

Fig. 4. PCA ordination of environmental variables. Ordination plot of samples with passively projected medians and coefficients of variation of all environmental variables ( $\boldsymbol{\Delta}$ - pond water; for other legend see Fig. 2).

factors in fishpond-margin fens. The Kendall tau correlations (Table 7) as well as scatter-plots (Fig. 6) confirm this fact. The water chemistry of fishpond water was similar to that of flooded- and poor fens. The rich-fen water chemistry was quite different (Table 8).

The Kruskal-Wallis test showed significant differences $(P<0.001)$ in the mean number of species among vegetation types. According to multiple comparisons of mean ranks of all groups, flooded fens are different from rich fens, and poor fens are different from moderately rich and rich-fen communities.

\section{DISCUSSION}

\section{High nutrient levels in fishpond-margin fens}

The nutrient levels found in fens at fishpond margins were extremely high, as expected. In some cases the concentration of major nutrients exceeded those measured directly in free pond water (Table 3). This is probably due to nutrient accumulation in fishpond sediments. In contrast to water in open fishpond, nutrients remain in upper parts of fen soil, from where they are released into soil water during water-level drawdown and decomposition of peat layer.

Comparison of water chemistry data published from other European and Northern-American fens show that unequalled values of $\mathrm{N}$ and $\mathrm{P}$ are attained in moderately rich fens. Fishpond-margin moderately rich fens had ammonium concentrations reaching temporarily up to $23.4 \mathrm{mg} \mathrm{l}^{-1}$. The extensive study of habitats of wetland Amblystegiaceae at a wide geographic range in Sweden (HEDENÄS \& KoOIJMAN 1996b) presents the highest ammonium concentrations of about $6 \mathrm{mg}^{-1}$. By analogy, one of the highest ammonium values reported from Northern-American fens are those of ANDERSON \& DAVIS (1997) who have found a maximum $2.28 \mathrm{mg} \mathrm{l}^{-1}$ of ammonium. Comparably high ammonium concentrations were found only from poor fens of other fishpond-margin mire in the central part of Czech 
Table 4. Descriptive statistics of water chemical variables. Mean and standard error were calculated by repeated measures ANOVA from four repeated measurements on 40 plots for each vegetation type (see Table 1)/pond water. The statistical significance of the tests of between subject effect (TWINSPAN clusters)/within subject effect (time) are in parentheses; ${ }^{*}$ - significant at $P<0.05$ and n.s. - not significant. (WTD - water table depth, $\mathrm{c}-$ conductivity, TP - Total P).

\begin{tabular}{|c|c|c|c|c|c|c|}
\hline Fen type/fishpond & $\begin{array}{l}\mathrm{WTD}(* / *) \\
(\mathrm{cm})\end{array}$ & $\mathrm{pH}(* / *)$ & $\begin{array}{l}\mathrm{c}\left(\mathrm{n} . \mathrm{s} . /{ }^{*}\right) \\
\left(\mu \mathrm{S} \mathrm{cm}{ }^{-1}\right)\end{array}$ & $\begin{array}{c}\mathrm{Ca}^{2+}(* / *) \\
\left(\mathrm{mg} \mathrm{l}^{-1}\right)\end{array}$ & $\begin{array}{c}\mathrm{Mg}^{2+}(* / *) \\
\left(\mathrm{mg} \mathrm{l}^{-1}\right)\end{array}$ & $\begin{array}{c}\mathrm{K}^{+}(* / \text { n.s. }) \\
\left(\mathrm{mg} \mathrm{l}^{-1}\right)\end{array}$ \\
\hline Flooded fen & $0 \pm 5$ & $4.74 \pm 0.29$ & $111 \pm 31$ & $19.63 \pm 4.53$ & $4.12 \pm 1.10$ & $1.94 \pm 0.63$ \\
\hline Poor fen & $-12 \pm 4$ & $4.67 \pm 0.21$ & $89 \pm 22$ & $8.62 \pm 3.20$ & $2.21 \pm 0.78$ & $1.52 \pm 0.45$ \\
\hline Medium-rich fen & $-3 \pm 3$ & $5.22 \pm 0.19$ & $112 \pm 20$ & $15.16 \pm 3.05$ & $3.36 \pm 0.74$ & $1.83 \pm 0.43$ \\
\hline Rich fen & $-8 \pm 7$ & $5.58 \pm 0.37$ & $167 \pm 40$ & $23.67 \pm 5.85$ & $7.59 \pm 1.42$ & $3.00 \pm 0.82$ \\
\hline Pond water & $-23 \pm 4$ & $7.23 \pm 0.21$ & $165 \pm 22$ & $22.73 \pm 3.20$ & $4.79 \pm 0.78$ & $3.48 \pm 0.45$ \\
\hline Fen type/fishpond & $\begin{array}{l}\mathrm{NH}_{4}^{+}(\mathrm{n} . \mathrm{s} . / \mathrm{n} . \mathrm{s} .) \\
\quad\left(\mathrm{mg} \mathrm{l}^{-1}\right)\end{array}$ & $\begin{array}{c}\mathrm{NO}_{3}^{-}(* / *) \\
\left(\mathrm{mg} \mathrm{l}^{-1}\right)\end{array}$ & $\begin{array}{l}\mathrm{PO}_{4}^{3-}(\text { n.s./n.s. }) \\
\left(\mathrm{mg} \mathrm{l}^{-1}\right)\end{array}$ & $\begin{array}{l}\text { TP (n.s./n.s.) } \\
\left(\mathrm{mg} \mathrm{l}^{-1}\right)\end{array}$ & $\begin{array}{c}\mathrm{Fe}\left(\mathrm{n} . \mathrm{s} . /^{*}\right) \\
\left(\mathrm{mg} \mathrm{l}^{-1}\right)\end{array}$ & $\begin{array}{l}\mathrm{SO}_{4}^{2-}\left(\mathrm{n}_{\mathrm{s}} \mathrm{s}\right) \\
\left(\mathrm{mg} \mathrm{l}^{-1}\right)\end{array}$ \\
\hline Flooded fen & $0.39 \pm 0.25$ & $0.18 \pm 1.00$ & $0.02 \pm 0.06$ & $0.07 \pm 0.12$ & $9.14 \pm 4.77$ & $41.46 \pm 7.11$ \\
\hline Poor fen & $0.24 \pm 0.17$ & $0.08 \pm 0.71$ & $0.04 \pm 0.04$ & $0.11 \pm 0.09$ & $12.58 \pm 3.37$ & $27.48 \pm 5.03$ \\
\hline Medium-rich fen & $0.52 \pm 0.16$ & $0.12 \pm 0.64$ & $0.09 \pm 0.04$ & $0.21 \pm 0.08$ & $9.12 \pm 3.22$ & $32.26 \pm 4.59$ \\
\hline Rich fen & $0.04 \pm 0.32$ & $5.38 \pm 1.29$ & $0.01 \pm 0.08$ & $0.05 \pm 0.16$ & $3.77 \pm 6.16$ & $29.21 \pm 9.18$ \\
\hline Pond water & $0.19 \pm 0.18$ & $0.28 \pm 0.74$ & $0.01 \pm 0.04$ & $0.07 \pm 0.09$ & $0.79 \pm 3.37$ & $38.63 \pm 5.03$ \\
\hline
\end{tabular}

Table 5. Minima and maxima of nutrient concentrations in water.

\begin{tabular}{|c|c|c|c|c|c|c|c|c|c|c|}
\hline \multirow[t]{2}{*}{ Fen type/ fishpond } & \multicolumn{2}{|c|}{$\begin{array}{c}\mathrm{NH}_{4}^{+} \\
\left(\mathrm{mg} \mathrm{l}^{-1}\right)\end{array}$} & \multicolumn{2}{|c|}{$\begin{array}{c}\mathrm{NO}_{3}^{-} \\
\left(\mathrm{mg} \mathrm{l}^{-1}\right)\end{array}$} & \multicolumn{2}{|c|}{$\begin{array}{l}\mathrm{PO}^{3-} \\
\left(\mathrm{mg}^{-1}\right)\end{array}$} & \multicolumn{2}{|c|}{$\begin{array}{l}\text { Total P } \\
\left(\mathrm{mg} \mathrm{l}^{-1}\right)\end{array}$} & \multicolumn{2}{|c|}{$\begin{array}{c}\mathrm{K}^{+} \\
\left(\mathrm{mg} \mathrm{l}^{-1}\right)\end{array}$} \\
\hline & Min. & Max. & Min. & Max. & Min. & Max. & Min. & Max. & Min. & Max. \\
\hline Flooded fen & 0.01 & 1.68 & 0.00 & 2.41 & 0.00 & 0.12 & 0.03 & 0.31 & 0.34 & 6.53 \\
\hline Poor fen & 0.00 & 1.69 & 0.00 & 0.89 & 0.00 & 0.37 & 0.04 & 0.92 & 0.06 & 5.27 \\
\hline Medium-rich fen & 0.00 & 13.44 & 0.00 & 0.97 & 0.00 & 1.39 & 0.03 & 4.83 & 0.12 & 5.12 \\
\hline Rich fen & 0.00 & 0.07 & 0.01 & 23.41 & 0.00 & 0.03 & 0.03 & 0.07 & 0.78 & 7.79 \\
\hline Pond water & 0.00 & 2.23 & 0.00 & 4.29 & 0.00 & 0.12 & 0.03 & 0.21 & 0.79 & 12.27 \\
\hline
\end{tabular}

Republic (NEUHÄUSL 1975) and from one dried-up poor fen meadow in the Western Carpathians (POULíČKOVÁ et al. 2003). In our study, nitrate concentration was highest in base-rich spring-fed fens. The same pattern is often reported (e.g. PERSSON 1962, TAHVANAINEN et al. 2002, HÁJEK \& HEKERA 2004, HEDENÄS \& KOOIJMAN 2004), but the maxima of nitrate concentration found in this study, above $20 \mathrm{mg} \mathrm{l}^{-1}$, are several fold larger than in the studies cited above. Moreover, we detected lower, but still rather high values of nitrates in flooded poor fens (up to $2.4 \mathrm{mg}^{-1}$ ) that obviously copy the values found in open fishponds. Phosphate and total phosphorus concentrations were higher in fishpond-margin moderately rich fens than in naturally "eutrophic" lacustrine marshes and fens (cf. BAYLEY \& MEWHORT 2004) and are comparable only with polluted fens of Netherlands (BOOTSMA \& WASSEN 1996) and with poor fens colonized by Juncus effusus in Germany (BERTRAM 1988). However, in rich fens, maximum phosphorus concentrations were low and did not 

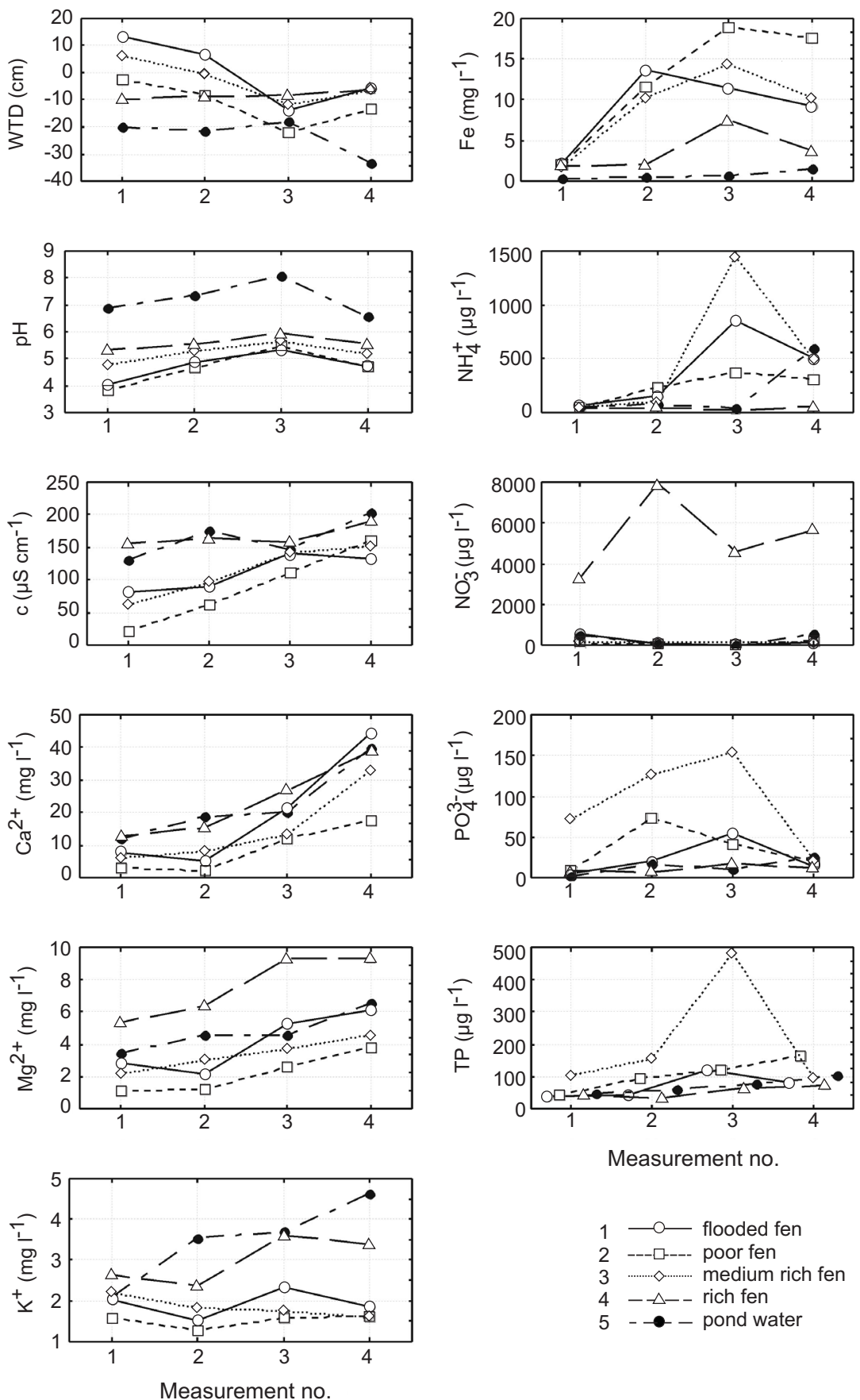

Measurement no.

$$
\begin{aligned}
& 1-\mathrm{O} \text { - flooded fen } \\
& 2 \text {--- } \square--- \text { poor fen } \\
& 3-\diamond \diamond . \cdots \cdots . . \text { medium rich fen } \\
& 4--\triangle-- \text { rich fen } \\
& 5 \text { - }- \text { pond water }
\end{aligned}
$$

Measurement no.

Fig. 5. Seasonal fluctuation of environmental factors for four fens types (see Table 1) and pond water. Factors were measured four times from April to September 2004 on 30 permanent plots and 10 adjacent fishponds (WTD - water-table level, c - conductivity). 

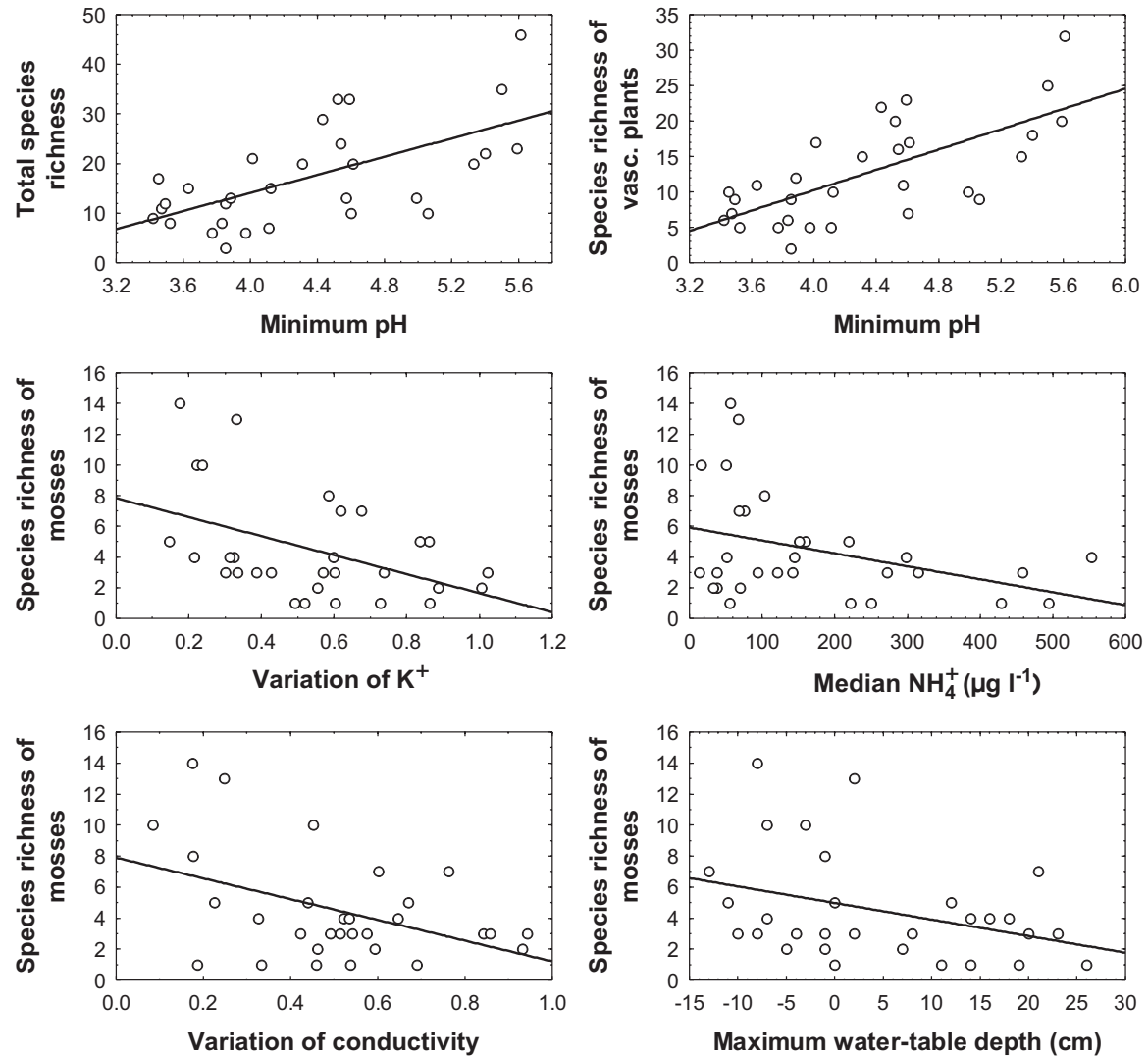

Fig. 6. Scatter-plots of main environmental variables selected by multiple regressions versus species richness. Line means linear regression between variables.

reach maximum concentrations reported from fens in literature (SLOBODDA 1979, VITT et al. 1995, BOOTSMA \& WASSEN 1996, HedenÄS \& KOOIJMAN 1996b, HÁJEK et al. 2002, TAHVANAINEN 2004). The different hydrology of rich fen remnants, which are mostly fed by springwater, is probably the reason. The low $\mathrm{P}$ level possibly maintains rich-fen vegetation even in N-enriched conditions. This hypothesis has support in ecological literature. Nutrient, especially phosphorus supply seemed to compensate for the intolerance to high mineral levels in poor-fen species $S$. fallax that populate rich fens in Netherlands (KOOIJMAN \& KANNE 1993). By analogy, LIMPENS et al. (2003) found that the expansion of $S$. fallax at the high deposition bog sites was limited by phosphorus. The expansion of Sphagnum flexuosum and $S$. fallax into rich fens results in acidification and consequent change into poor-fen vegetation (BELTMAN et al. 2001, HÁJKOVÁ \& HÁJEK 2003). All other vegetation types have high levels of dissolved P similar to that found in open fishpond. The fishpond-to-fen connection is evident in these cases. High phosphorus supply is presumably responsible for development of poor fens even under high $\mathrm{Ca}^{2+}$ levels about $20 \mathrm{mg}^{1-1}$ (see also HÁJEK et al. 2002) as is further suggested by the correlation between fishpond- and poor-fen water chemistry (Table 8). 
Table 6. Result of stepwise multiple regression of species richness on environmental factors. For scatter-plots see Fig. 6. (WTDMax - maximum of water-table depth; $\mathrm{VK}^{+}$- variation of $\mathrm{K}^{+}$; cover $\mathrm{E}_{1}$ - cover of herb layer; $\mathrm{Vc}-$ variation of conductivity; $T$ - test value of the hypothesis that the intercept is equal to 0 ; Adjusted $R^{2}$ - coefficient of multiple determination).

\begin{tabular}{|c|c|c|c|c|c|}
\hline $\begin{array}{l}\text { Regression } \\
\text { coefficient }\end{array}$ & s.e. & $\begin{array}{l}\text { Stand. } \\
\text { regression } \\
\text { coefficient }\end{array}$ & $T$ & Sig. & $\begin{array}{l}\text { Adjusted } R^{2} \\
\text { (cumulative) }\end{array}$ \\
\hline
\end{tabular}

\begin{tabular}{|c|c|c|c|c|c|c|}
\hline \multicolumn{6}{|c|}{ Total species richness } & 0.366 \\
\hline WTDMax & -0.476 & 0.119 & -0.541 & -4.011 & 0.000 & 0.488 \\
\hline cover total & -0.273 & 0.098 & -0.369 & -2.785 & 0.010 & 0.591 \\
\hline \multicolumn{7}{|c|}{ Species richness of vascular plants } \\
\hline pHMin & 8.201 & 1.251 & 0.791 & 6.556 & 0.000 & 0.460 \\
\hline WTDMax & -0.277 & 0.083 & -0.445 & -3.349 & 0.002 & 0.543 \\
\hline cover total & -0.152 & 0.068 & -0.291 & -2.226 & 0.035 & 0.602 \\
\hline \multicolumn{7}{|c|}{ Species richness of mosses } \\
\hline $\mathrm{VK}^{+}$ & -5.382 & 1.429 & -0.392 & -3.767 & 0.001 & 0.175 \\
\hline $\mathrm{NH}_{4}^{+}$Median & -0.010 & 0.002 & -0.435 & -4.034 & 0.000 & 0.300 \\
\hline cover $E_{1}$ & 0.083 & 0.018 & 0.513 & 4.540 & 0.000 & 0.401 \\
\hline WTDMax & -0.181 & 0.037 & -0.600 & -4.926 & 0.000 & 0.562 \\
\hline cover total & -0.097 & 0.029 & -0.385 & -3.351 & 0.003 & 0.689 \\
\hline \multicolumn{7}{|c|}{ Species richness of mosses, coefficient of variance of $\mathrm{K}^{+}$and cover total were eliminated from the model } \\
\hline $\mathrm{Vc}$ & -9.125 & 2.048 & -0.600 & -4.457 & 0.000 & 0.165 \\
\hline WTDMax & -0.148 & 0.037 & -0.493 & -4.046 & 0.000 & 0.374 \\
\hline pHMedian & 1.983 & 0.755 & 0.326 & 2.626 & 0.015 & 0.476 \\
\hline $\mathrm{K}^{+} \mathrm{Max}$ & -1.033 & 0.305 & -0.504 & -3.386 & 0.002 & 0.550 \\
\hline $\mathrm{Ca}^{2+}$ Mean & 0.107 & 0.042 & 0.342 & 2.520 & 0.019 & 0.630 \\
\hline
\end{tabular}

A disaccord between potassium concentrations in fishpond water (high) and in fen water (lower) was found. Potassium concentrations measured in the fens were within the ranges reported for unpolluted spring-fed fens (HÁJEK et al. 2002, TAHVANAINEN 2004). Maximum potassium concentrations, however, correlated with the cover of vascular plants. This corresponds to the relationship between $\mathrm{K}^{+}$concentration and productivity found by WASSEN et al. (1990). The pattern suggests K-limitation of the study fens; plants take up all potassium when its concentration increases.

Apart from extreme nutrient supply to fishpond-margin fens, the major patterns in species richness and species composition do not differ from pristine fens to such an extent as could be expected. The major gradients in both species composition and species richness more or less correspond to those most often reported in literature (WHEELER \& PROCTOR 2000, ØKLAND et al. 2001, HÁJKOVÁ \& HÁJEK 2003, 2004, TAHVANAINEN 2004).

\section{Species richness}

Water $\mathrm{pH}$ accounted for the principal part of variation in vascular plant species richness. Due to high seasonal fluctuation of $\mathrm{pH}$, the minimum $\mathrm{pH}$ was a better predictor than mean or maximum $\mathrm{pH}$. The temporarily high $\mathrm{pH}$ values that occurred in poor fens in summer were 
Table 7. Kendall tau correlation coefficients between total species richness, species richness of mosses and species richness of vascular plants versus significant environmental variables. Significance levels: ${ }^{*}-P<0.05$, ** $-P<0.01,{ }^{* * *}-P<0.001$, n.s. - not significant.

\begin{tabular}{lccc} 
Species richness & $\begin{array}{c}\text { Species richness } \\
\text { of vascular plants }\end{array}$ & $\begin{array}{c}\text { Species richness } \\
\text { of mosses }\end{array}$ \\
\hline Maximum water-table depth & n.s. & n.s. & $-0.25^{*}$ \\
Variation of water-table depth & n.s. & $-0.26^{* *}$ & n.s. \\
Mean pH & $0.41^{* *}$ & $0.44^{* * *}$ & $0.26^{*}$ \\
Median pH & $0.38^{* *}$ & $0.40^{* *}$ & $0.27^{*}$ \\
Minimum pH & $0.42^{* *}$ & $0.47^{* *}$ & n.s. \\
Variation of pH & $-0.38^{* *}$ & $-0.42^{* *}$ & $-0.26^{*}$ \\
Variation of conductivity & $-0.33^{* *}$ & $-0.32^{*}$ & n.s. \\
Minimum $\mathrm{Ca}^{2+}$ & $0.34^{* *}$ & $0.34^{* *}$ & $0.30^{*}$ \\
Variation of $\mathrm{Ca}^{2+}$ & $-0.26^{*}$ & $-0.26^{*}$ & n.s. \\
Variation of $\mathrm{Mg}^{2+}$ & $-0.26^{*}$ & $-0.27^{*}$ & n.s. \\
Variation of $\mathrm{K}^{+}$ & n.s. & n.s. & $-0.32^{*}$ \\
Median $\mathrm{NO}_{3}^{-}$ & n.s. & n.s. & $0.28^{*}$ \\
Variation of $\mathrm{PO}_{4}^{3-}$ & $-0.26^{*}$ & n.s. & n.s. \\
Variation of total P & n.s. & n.s. & $-0.33^{*}$ \\
\hline
\end{tabular}

probably caused by increased microbial activity and algae photosyntesis (for another example see MUÑOZ et al. 2003). The correlation between $\mathrm{pH}$ and vascular plant species richness has been repeatedly confirmed in mires (SCHUSTER \& DIEKMAN 2003, CHYTRÝ et al. 2003, TAHVANAINEN 2004) and it seems to be valid across various scales (HÁJKOVÁ \& HÁJEK $2003,2004)$. The modern calcicole/calcifuge disparity in species pool that resulted from historical processes (PÄRTEL 2002, EWALD 2003) is one possible explanation, but the ecophysiological causes cannot be omitted (TYLER 2003). The second independent predictor, maximum water level, decreases species richness due to high concentration of toxic iron (SNOWDEN \& WHEELER 1993), inducing anoxia and hindered seedling establishment. The pattern in bryophyte species richness found in nutrient-rich fishpond-margin fens seems to be caused primarily by local ecological factors. The major predictor of bryophyte species richness is the extent of conductivity variation. There are probably only a few bryophyte species that overcome widely fluctuating mineral richness. Independently of this pattern, increasing potassium concentration correlated negatively with species richness, probably due to the acceleration of the growth of dominant species. Maximum water level and base saturation also significantly contributed to the model. However, when conductivity variation and maximum $\mathrm{K}^{+}$were excluded from the multiple regression, the explained variation declined by $50 \%$. These results suggest that the historical explanation of the correlation between species richness and $\mathrm{pH} /$ calcium gradient as suggested by PÄRTEL (2002) cannot be extrapolated to bryophytes. A similar lack of relationship between bryophytes species density and pH was found also by HÁJKOVÁ \& HÁJEK (2004).

\section{Water level and nutrients}

The role of water-level dynamics in nutrient-enriched fens is complex. At the landscape scale, the high correlation between water level and vegetation gradient is partly caused by 
Table 8. Pearson correlation coefficients between water chemistry of each vegetation type and fishpond water. Significance levels: $* *-P<0.01, * * *-P<0.001$, n.s. - not significant.

\begin{tabular}{llllll} 
Fen type/fishpond & Flooded fen & Poor fen & Medium-rich fen & Rich fen & Pond water \\
\hline Flooded fen & 1.00 & $0.79 * * *$ & $0.86^{* * *}$ & n.s. & $0.59^{* * *}$ \\
Poor fen & $0.79 * * *$ & 1.00 & $0.79 * * *$ & n.s. & $0.58^{* * *}$ \\
Medium-rich fen & $0.86^{* * *}$ & $0.79 * * *$ & 1.00 & n.s. & n.s. \\
Rich fen & n.s. & n.s. & n.s. & 1.00 & $0.39 * *$ \\
Pond water & $0.59 * * *$ & $0.58^{* * *}$ & n.s. & $0.39 * *$ & 1.00 \\
\hline
\end{tabular}

covariation with $\mathrm{pH}$. In contrast to rich fens, poor acidic fens occur often in habitats with fluctuating water table. Rich-fen vegetation is strongly confined to water level not falling below ca. 20-30 cm (KOPECKÝ 1960, FLINTROP 1994, HÁJKOVÁ et al. 2004). In our study, however, only fluctuation in water level correlated with poor-rich gradient, while mean water level controls the second, independent gradient in species composition. It separated Utricularia- and tall-sedge fens. Maximum water level did not correlate significantly with the two major gradients, but its effect on vegetation variation was revealed by CCA (see also WIERDA et al. 1997, HÁJKOVÁ \& HÁJEK 2004). Its major effect lies in lowering species richness (Table 6).

The importance of the fluctuation of water level in buffering the effect of nutrient-rich fishpond water can be assessed by numerous indices. High ammonium levels in fen water, sometimes higher than those measured directly in fishponds, are most likely caused by peat decomposition that takes place when water level decreases. The high water level can therefore disable the nutrient release. However, when the water level rises above the peat layer, the nutrient-enriched fishpond water gets directly into the moss layer. The P-rich fishpond water makes the dominance of acidifying Sphagnum flexuosum possible even in calcium-rich fens. The true rich-fen vegetation can survive only at spring outflows away from direct influence of fishpond water, as is indicated by low P-level. The overflowing of rich fens by fishpond water would probably cause their change into poor fens. Currently, fishpond-margin rich fens do not significantly differ from poor fens in calcium nor in $\mathrm{pH}$, but in phosphate concentrations. The mean calcium concentration in flooded poor fens with Sphagnum denticulatum is nearly $20 \mathrm{mg}^{-1}$, much higher than reported in literature (but see HÁJEK et al. 2002). Such a high calcium concentration in poor fens can be explained only by increased tolerance of Sphagnum to calcium under high nutrient (N, P, K) levels (KOOIJMAN \& KANNE 1993, HÁJEK et al. 2002).

Acknowledgements: The research was performed within the long-term research plans of Masaryk University (MSM 0021622416) and Czech Academy of Sciences (AV0Z 60050516) and it was also supported by Doctoral Project GACR no. 524/05/H536.

\section{REFERENCES}

ANDERSON D.S. \& DAVIS R.B. (1997): The vegetation and its environments in Maine peatlands. Canad. J. Bot. 75: 1785-1805.

ASADA T. (2002): Vegetation gradients in relation to temporal fluctuation of environmental factors in Bekanbeushi peatland. Ecol. Res. (Tokyo) 17: 505-518. 
BAYLEY S.E. \& MEWHORT R.L. (2004): Plant community structure and functional differences between marshes and fens in the southern boreal region of Alberta, Canada. Wetlands 24: 277-294.

Beltman B., VAN DEN BROEK T., BARENDREgT A., Bootsma M.C. \& Grootjans A.P. (2001) Rehabilitation of acidified and eutrophied fens in The Netherlands: Effects of hydrologic manipulation and liming. Ecol. Engin. 17: 21-31.

BERTRAM R. (1988): Pflanzengesselschaften der Torfstiche nordniedersächsischer Moore und die Abhängigkeit dieser Vegetationseinheiten von der Wasserqualität. Diss. Bot. 126: 1-192.

BoOtsma M.C. \& WASSEN M.J. (1996): Environmental conditions and fen vegetation in three lowland mires. Vegetatio 127: 173-189.

CHAPIN C.T., BRIDGHAM S.D. \& PASTOR J. (2004): pH and nutrient effects on above-ground net primary production in a Minnesota, USA bog and fen. Wetlands 24: 186-201.

ChYTRÝ M., TichÝ L., Holt J. \& BotTA-DukÁT Z. (2002): Determination of diagnostic species with statistical fidelity measures. J. Veg. Sci. 13: 79-90.

CHYTRÝ M., TICHÝ L. \& ROLEČEK J. (2003): Local and regional patterns of species richness in central European vegetation types along the $\mathrm{pH} /$ calcium gradient. Folia Geobot. 38: 429-442.

DIERSCHKE H. (1969): Grundwasser-Ganglinien einiger Pflanzengesellschaften des Holtumer Noores östlich von Bremen. Vegetatio 17: 372-383.

DU RIETZ G.E. (1949): Huvudenheter och huvudgränser i svensk myrvegetation (Main units and main limits in Swedish mire vegetation). Svensk Bot. Tidskr. 43: 279-304.

EWALD J. (2003): The calcareous riddle: Why are there so many calciphilous species in the Central European flora? Folia Geobot. 38: 357-366.

FLINTROP T. (1994): Ökologische Charakterisierung des Caricetum davallianae durch Grundwasserstands- und pH-Messungen. Ber. Reinhold-Tüxen-Ges. 6: 83-100.

FOJT W. \& HARDING M. (1995): 30 years of change in the vegetation communities of 3 valley mires in Suffolk, England. J. Appl. Ecol. 32: 561-577.

GUNNARSSON U., RYDIN H. \& SJÖRS H. (2000): Diversity and pH changes after 50 years on the boreal mire Skattlösbergs Stormosse, Central Sweden. J. Veg. Sci. 11: 277-286.

HÁJEK M., HeKerA P. \& HÁJKOvÁ P. (2002): Spring fen vegetation and water chemistry in the western Carpathian flysch zone. Folia Geobot. 37: 205-224.

HÁJEK M. \& HEKERA P. (2004): Can seasonal variation in fen water chemistry influence the reliability of vegetation-environment analyses? Preslia 76: 1-14.

HÁJKOVÁ P. \& HÁJEK M. (2003): Species richness and above-ground biomass of poor and calcareous spring fens in the flysch West Carpathians, and their relationships to water and soil chemistry. Preslia 75: 271-287.

HÁJKOVÁ P. \& HÁJEK M. (2004): Bryophyte and vascular plant responses to base-richness and water level gradients in Western Carpathian Sphagnum-rich mires. Folia Geobot. 39: 335-351.

HÁJKOVÁ P., WOLF P. \& HÁJEK M. (2004): Environmental factors and Carpathian spring fen vegetation: the importance of scale and temporal variation. Ann. Bot. Fenn. 41: 249-262.

HEDENÄS L. \& KoOIJMAN A.M. (1996a): Förändringar i rikkärrsvegetationen SV om Mellansjön i Västergötland (Changes in vegetation of a rich fen in Västergötland, Sweden). Svensk Bot. Tidskr. 90: $113-121$.

HedENÄS L. \& KoOIJMAN A.M. (1996b): Phylogeny and habitat adaptations within a monophyletic group of wetland moss genera (Amblystegiaceae). Pl. Syst. Evol. 199: 33-52.

HEDENÄS L. \& KOOIJMAN A.M. (2004): Habitat differentiation within Palustriella. Lindbergia 29: 40-50.

HILL M.O. (1979): TWINSPAN - a FORTRAN program for arranging multivariate data in an ordered two-way table by classification of individuals and attributes. Ecology and Systematics, Cornell University, Ihtaca.

JOHNSON J.B. \& STEINGRAEBER D.A. (2003): The vegetation and ecological gradients of calcareous mires in the South Park valley, Colorado. Canad. J. Bot. 81: 201-219.

KOERSELMAN W., BAKKER S.A. \& BLOM M. (1990): Nitrogen, phosphorus and potassium budgets for 2 small fens surrounded by heavily fertilized pastures. J. Ecol. 78: 428-442.

KOOIJMAN A.M. \& KANNE D. (1993): Effect of water chemistry, nutrient supply and interspecific interaction on the replacement of Sphagnum subnitens by Sphagnum fallax in fens. J. Bryol. 17: 431-438. 
KOPECKÝ K. (1960): Fytocenologická studie slatinných luk v severovýchodních Čechách (Phytosociological study on mire meadows in northeastern Bohemia). Rozpr. Českoslov. Akad. Věd, Ser. Math.-Natur. 70/4: $1-64$.

KubÁt K., Hrouda L., ChrteK J. Jun., Kaplan Z., Kirschner J. \& ŠTĚPÁneK J. (eds.) (2002): Key to the Flora of the Czech Republic. Academia, Praha.

KUČERA J. \& VÁŇA J. (2003): Check- and Red List of bryophytes of the Czech Republic (2003). Preslia 75: $193-222$.

LAZAR J. (1978): Problematika povrchových vod v Třeboňské pánvi. (The issues of water bodies in Třeboň basin). In: JENÍK J. \& PřIBIL S. (eds.): Ekologie a ekonomika Třeboňska, I. (Ecology and Economics of Třebon̆ Region, I.), ČSAV, Třeboň, pp. 125-130.

LEPŠ J. \& ŠMILAUER P. (2003): Multivariate analysis of ecological data using CANOCO. University Press, Cambridge, UK.

Limpens J., TOMASSEN H. B. M. \& BeRENDSE F. (2003): Expansion of Sphagnum fallax in bogs: striking the balance between $\mathrm{N}$ and $\mathrm{P}$ availability. J. Bryol. 25: 83-90.

Muñoz J., Aldasoro J.J., NEGRo A., DE Hoyos C. \& VEGA J.C. (2003): Flora and water chemistry in a relictic mire complex: the Sierra Segundera mire area (Zamora, NW Spain). Hydrobiologia 495: 1-16.

NAVRÁTILOVÁ J. \& NAVRÁTIL J. (2005a): Hlavní typy nelesní rašeliništní vegetace Třeboňské pánve. (The main types of non-forest mire vegetation in Třeboň basin). Sbor. Jihočesk. Muz. v Čes. Budějovicich Př́r. Vědy 45: 47-58.

NAVRÁTILOVÁ J. \& NAVRÁTIL J. (2005b): Seasonal fluctuation of environmental factors in relation to vegetation gradients in fishpond mires. Preslia 77: 405-418.

NEKOLA J.C. (2004): Vascular plant compositional gradients within and between Iowa fens. J. Veg. Sci. 15: $771-780$.

NEUHÄUSL R. (1975): Hochmoore am Teich Velké Dářko. Vegetace ČSSR, ser. A, 9. Academia, Praha.

ØKLAND R.H. (1996): Are ordination and constrained ordination alternative or complementary strategies in general ecological studies? J. Veg. Sci. 7: 289-292.

ØKLAND R.H., ØKLAND T. \& RYDGREN K. (2001): A Scandinavian perspective on ecological gradients in north-west European mires: reply to Wheeler and Proctor. J. Ecol. 89: 481-486.

Olde VenterinK H., WASSEN M.J., Belgers J.D. M. \& VERHOEVEN J.T.A. (2001): Control of environmental variables on species density in fens and meadows: importance of direct effects and effects through community biomass. J. Ecol. 89: 1033-1040.

Olde Venterink H., WASSEN M.J., Verkroost A.W.M. \& DE Ruiter P.C. (2003): Species richness-productivity patterns differ between N-, P-, and K-limited wetlands. Ecology 84: 2191-2199.

PÄRTEL M. (2002): Local plant diversity patterns and evolutionary history at the regional scale. Ecology 83: 2361-2366.

PAUli D., PEINTINGER M. \& SCHMID B. (2002): Nutrient enrichment in calcareous fens: effects on plant species and community structure. Basic Appl. Ecol. 3: 255-266.

PAULISSEN M. P.C.P., VAN DER VEN P.J.M., DEES A.J. \& BOBBINK R. (2004): Differential effects of nitrate and ammonium on three fen bryophyte species in relation to pollutant nitrogen input. New Phytol. 164: 451-458.

PECHAR L., PŘIKRYL I. \& FAINA R. (2002): Hydrobiological evaluation of Třebon̆ fishponds since the end of the nineteenth century. In: KVĚT J., JENÍK J. \& SOUKUPOVÁ L. (eds.) Freshwater wetlands and their sustainable future, Man and the biosphere series 28, Panthenon Publishing Group Limited, Lancaster, pp. 31-61.

PERSSON Ă. (1962): Mire and spring vegetation in an area north of Lake Torneträsk, Torne Lappmark, Sweden. II. Habitat conditions. Opera Bot. 6/3: 1-100

POUlíČKOVÁ A., BOGDANOVÁ K., HEKERA P. \& HÁJKOVÁ P. (2003): Epiphytic diatoms of the spring fens in the flysh area of the Western Carpathians. Biologia (Bratislava) 58: 749-757.

RYBNÍČEK K. (1974): Die Vegetation der Moore im südlichen Teil der Böhmisch-Mährischen Höhe. Vegetace ČSSR A6, Academia, Praha.

SCHUSTER B. \& DIEKMAN M. (2003): Changes in species density along the soil pH gradient - Evidence from German plant communities. Folia Geobot. 38: 367-379.

SJÖRS H. (1952): On the relation between vegetation and electrolytes in north Swedish mire waters. Oikos 2: $241-258$. 
SLOBODDA S. (1979): Die Moosvegetation ausgewählter Pflanzengesselschaften des NSG "Peenwiesen bei Gützkow" unter Berücksichtigung der ökologischen Bedingungen eines Flußtalmoor-Standortes. Feddes Repert. 90: 481-518.

SNOWDEN R.E.D. \& WHEELER B.D. (1993): Iron toxicity to fen plant-species. J. Ecol. 81: 35-46.

SOMODI I. \& BOTTA-DUKÁT Z. (2004): Determinants of floating island vegetation and succession in a recently flooded shallow lake, Kis-Balaton (Hungary). Aquatic Bot. 79: 357-366.

TAHVANAINEN T. (2004): Water chemistry of mires in relation to the poor-rich vegetation gradient and contrasting geochemical zones of the nort-eastern Fennoscandian shield. Folia Geobot. 39: 353-369.

TAhVANAinen T., SAllantaus T., HeikKILÄ R. \& TOlONEN K. (2002): Spatial variation of mire surface water chemistry and vegetation in north-eastern Finland. Ann. Bot. Fenn. 39: 235-251.

TAhVAnAinen T., SAllantaus T. \& HeIKKILÄ R. (2003): Seasonal variation of water chemical gradients in three boreal fens. Ann. Bot. Fenn. 40: 345-355.

TER BRAAK C.J.F. \& ŠMILAUER P. (1998): CANOCO 4. CANOCO reference manual and user's guide to Canoco for Windows. Centre of Biometry, Wageningen.

TER BRAAK C.J.F. \& ŠMILAUER P. (2002): CANOCO reference manual and CanoDraw for Windows user's guide: software for canonical community ordination Version 4.5. Microcomputer Power, Ithaca.

TYLER G. (2003): Some ecophysiological and historical approaches to species richness and calcicole/calcifuge behaviour - Contribution to a debate. Folia Geobot. 38: 419-428

VAN DER MAAREL E. (1979): Transformation of cover-abundance values in phytosociology and its effect on community similarity. Vegetatio 39: 97-114.

VITT D.H., BAYLEY S. E. \& JIN T.L. (1995): Seasonal variation in water chemistry over a bog-rich fen gradient in continental western Canada. Canad. J. Fish. Aquatic Sci. 52: 587-606.

WAssen M.J., BAREndregt A., PAlczYnski A., DE AMIDY J.T. \& DE MARS H. (1990): The relationship between fen vegetation gradients, groundwater flow and flooding in an undrained valley mire at Biebrza, Poland. J. Ecol. 78: 1106-1122.

VESECKÝ J. (ed.) (1961): Podnebi Československé socialistické republiky (Climate of the Czechoslovak Socialistic Republic). Tables. Hydrometeorological Institute, Praha.

WhEELER B.D. \& PROCTOR M.C.F. (2000): Ecological gradients, subdivisions and terminology of north-west European mires. J. Ecol. 88: 187-203.

Wierda A., Fresco L.F.M., Grootjans A.P. \& VAN DigGELEN R. (1997): Numerical assessment of plant species as indicators of the groundwater regime. J. Veg. Sci. 8: 707-716.

Received 1 April 2005, revision received and accepted 22 November 2005

Encl. Appendix pp. 374-376 


\section{APPENDIX}

Species scores along the first and second DCA axes. Second column shows the vegetation type (1- flooded fen, 2 - poor fen, 3 - medium-rich fen, 4 - rich fen; see Table 1) to which the species reaches considerable fidelity (phi coefficient above 20).

\begin{tabular}{|c|c|c|c|}
\hline Species & Vegetation type & DCA1 score & DCA2 score \\
\hline Sphagnum denticulatum & 1 & -0.802 & -0.950 \\
\hline Sphagnum fallax & 2 & -0.759 & 3.906 \\
\hline Sphagnum papillosum & 2 & -0.690 & 3.634 \\
\hline Utricularia ochroleuca & 2 & -0.424 & 2.512 \\
\hline Carex limosa & - & -0.374 & 3.234 \\
\hline Phragmites australis & - & -0.021 & 1.835 \\
\hline Betula pubescens & 2 & 0.163 & 4.297 \\
\hline Polytrichum commune & 2,4 & 0.320 & 2.806 \\
\hline Utricularia intermedia & 1 & 0.360 & -0.405 \\
\hline Juncus bulbosus & 1,4 & 0.539 & -0.269 \\
\hline Eriophorum angustifolium & 2 & 0.550 & 0.880 \\
\hline Iris pseudacorus & 1 & 0.702 & 1.432 \\
\hline Nymphaea candida & 1 & 0.738 & 0.556 \\
\hline Carex rostrata & 2 & 0.767 & 3.139 \\
\hline Lycopus europaeus & 1 & 0.806 & 0.456 \\
\hline Oxycoccus palustris & 4 & 0.845 & 2.272 \\
\hline Carex lasiocarpa & 1 & 0.932 & 0.830 \\
\hline Carex elata & 1 & 0.982 & 1.324 \\
\hline Sphagnum cuspidatum & - & 0.984 & 2.919 \\
\hline Lysimachia thyrsiflora & 3 & 1.059 & 1.802 \\
\hline Picea abies & 3 & 1.062 & 3.056 \\
\hline Juncus filiformis & - & 1.175 & 3.637 \\
\hline Sphagnum flexuosum & - & 1.204 & 1.355 \\
\hline Calamagrostis canescens & - & 1.215 & 2.007 \\
\hline Bidens cernuus & 3 & 1.262 & 1.301 \\
\hline Utricularia australis & 3 & 1.262 & 1.301 \\
\hline Sphagnum inundatum & 3 & 1.314 & 1.858 \\
\hline Juncus effusus & 3 & 1.371 & 2.835 \\
\hline Drosera rotundifolia & 4 & 1.386 & 2.609 \\
\hline Agrostis canina & 3 & 1.443 & 0.957 \\
\hline Lythrum salicaria & 3 & 1.493 & 1.928 \\
\hline Carex canescens & 3 & 1.505 & 2.197 \\
\hline Lysimachia vulgaris & 3 & 1.581 & 1.656 \\
\hline Carex nigra & 3 & 1.870 & 2.908 \\
\hline Epilobium palustre & 3 & 1.911 & 2.114 \\
\hline Rhynchospora alba & 4 & 1.914 & 0.405 \\
\hline Peucedanum palustre & 3 & 1.954 & 1.977 \\
\hline Pinus sylvestris & 4 & 1.964 & 2.376 \\
\hline Typha angustifolia & 3 & 2.008 & 2.531 \\
\hline Eleocharis palustris agg. & 3 & 2.036 & 0.834 \\
\hline Glyceria fluitans & 3 & 2.036 & 0.834 \\
\hline Phalaris arundinacea & 3 & 2.036 & 0.834 \\
\hline Ranunculus flammula & 3 & 2.036 & 0.834 \\
\hline Scutellaria galericulata & 3 & 2.036 & 0.834 \\
\hline Sparganium emersum & 3 & 2.036 & 0.834 \\
\hline Carex chordorrhiza & 3 & 2.122 & 2.871 \\
\hline
\end{tabular}




\begin{tabular}{|c|c|c|c|}
\hline Species & Vegetation type & DCA1 score & DCA2 score \\
\hline Galium palustre & 3 & 2.218 & 1.623 \\
\hline Sphagnum subsecundum & - & 2.225 & 2.515 \\
\hline Warnstorfia exannulata & 3 & 2.252 & 2.051 \\
\hline Potentilla palustris & 3 & 2.275 & 2.330 \\
\hline Calliergon stramineum & 3 & 2.539 & 1.915 \\
\hline Molinia caerulea & 4 & 2.576 & 2.384 \\
\hline Equisetum fluviatile & 3,4 & 2.589 & 2.403 \\
\hline Frangula alnus & 3 & 2.591 & 1.904 \\
\hline Hamatocaulis vernicosus & 3 & 2.669 & 1.025 \\
\hline Helodium blandowii & 3 & 2.732 & 2.012 \\
\hline Sphagnum platyphyllum & 3 & 2.756 & 1.386 \\
\hline Carex diandra & 3 & 2.793 & 2.977 \\
\hline Sphagnum majus & 3 & 2.793 & 2.977 \\
\hline Betula pendula & - & 2.827 & 2.184 \\
\hline Calamagrostis epigejos & 3 & 2.829 & 1.025 \\
\hline Sphagnum fimbriatum & 3 & 2.846 & 1.258 \\
\hline Calliergonella cuspidata & 4 & 2.855 & 1.266 \\
\hline Brachythecium rivulare & 3 & 2.858 & 1.613 \\
\hline Carex acuta & 3 & 2.858 & 1.613 \\
\hline Chiloscyphus polyanthos & 3 & 2.858 & 1.613 \\
\hline Drepanocladus aduncus & 3 & 2.858 & 1.613 \\
\hline Lophocolea bidentata & 3 & 2.874 & 0.902 \\
\hline Menyanthes trifoliata & 3 & 2.897 & 2.859 \\
\hline Salix cinerea & 3 & 2.913 & 1.856 \\
\hline Sphagnum palustre & 3,4 & 2.918 & 0.964 \\
\hline Drosera intermedia & 1,4 & 2.958 & 0.688 \\
\hline Sphagnum teres & 3 & 3.018 & 2.628 \\
\hline Utricularia minor & 4 & 3.067 & 2.225 \\
\hline Alnus glutinosa & 4 & 3.177 & 2.631 \\
\hline Polytrichum strictum & 4 & 3.232 & 1.806 \\
\hline Carex echinata & 4 & 3.248 & 2.706 \\
\hline Juncus alpinoarticulatus & 4 & 3.296 & 1.028 \\
\hline Viola palustris & 4 & 3.310 & 1.529 \\
\hline Aulacomnium palustre & 4 & 3.316 & 1.678 \\
\hline Carex dioica & 4 & 3.350 & 1.315 \\
\hline Eriophorum gracile & 4 & 3.350 & 1.315 \\
\hline Hydrocotyle vulgaris & 4 & 3.350 & 1.315 \\
\hline Calluna vulgaris & 4 & 3.354 & 1.896 \\
\hline Nardus stricta & 3 & 3.358 & 2.410 \\
\hline Sphagnum contortum & 4 & 3.400 & 1.362 \\
\hline Aneura pinguis & 4 & 3.407 & 1.368 \\
\hline Holcus lanatus & 4 & 3.604 & 1.855 \\
\hline Potentilla erecta & 4 & 3.635 & 1.785 \\
\hline Sphagnum warnstorfii & 4 & 3.654 & 1.663 \\
\hline Succisa pratensis & 4 & 3.660 & 1.713 \\
\hline Drosera anglica & 4 & 3.765 & 1.454 \\
\hline Cirsium palustre & 4 & 3.810 & 1.798 \\
\hline Juncus articulatus & 4 & 3.820 & 1.727 \\
\hline Carex panicea & 4 & 3.832 & 1.523 \\
\hline Angelica sylvestris & 4 & 3.850 & 1.238 \\
\hline Briza media & 4 & 3.850 & 1.238 \\
\hline
\end{tabular}


J. Navrátilová et al.

\begin{tabular}{lccc} 
Species & Vegetation type & DCA1 score & DCA2 score \\
\hline Carex demissa & 4 & 3.850 & 1.238 \\
Carex flava & 4 & 3.850 & 1.238 \\
Eriophorum latifolium & 4 & 3.850 & 1.238 \\
Fissidens adianthoides & 4 & 3.850 & 1.238 \\
Philonotis fontana & 4 & 3.850 & 1.238 \\
Pinguicula vulgaris & 4 & 3.850 & 1.238 \\
Rhytidiadelphus squarrosus & 4 & 3.850 & 1.238 \\
Salix aurita & 4 & 3.850 & 1.238 \\
Scirpus sylvaticus & 4 & 3.850 & 1.238 \\
Sphagnum subnitens & 4 & 3.850 & 1.238 \\
Tomenthypnum nitens & 4 & 3.850 & 1.238 \\
Bryum pseudotriquetrum & 4 & 3.919 & 1.461 \\
Carex pulicaris & 4 & 3.919 & 1.461 \\
Parnassia palustris & 4 & 3.933 & 1.511 \\
Galium uliginosum & 4 & 3.953 & 1.576 \\
Scorpidium cossonii & 4 & 3.953 & 1.576 \\
Trichophorum alpinum & 4 & 3.976 & 1.659 \\
Campylium stellatum & 4 & 4.055 & 1.933 \\
Carex davalliana & 4 & 4.055 & 1.933 \\
Equisetum sylvaticum & 4 & 4.055 & 1.933 \\
Linum catharticum & 4 & 4.055 & 1.933 \\
\hline
\end{tabular}

